\title{
A Comparative Analysis of Tanazul And Conditional Hibah In Preference Shares
}

\section{Azlin Alisa Ahmad, Siti Mutiara Mohd Azman, Nadhirah Nordin}

To Link this Article: http://dx.doi.org/10.6007/IJARBSS/v11-i2/8885 DOI:10.6007/IJARBSS/v11-i2/8885

Received: 20 January 2021, Revised: 13 February 2021, Accepted: 20 February 2021

Published Online: 28 February 2021

In-Text Citation: (Ahmad et al., 2021)

To Cite this Article: Ahmad, A. A., Azman, S. M. M., \& Nordin, N. (2021). A Comparative Analysis of Tanazul And Conditional Hibah In Preference Shares. International Journal of Academic Research in Business and Social Sciences, 11(2), 771-783.

\section{Copyright: (c) 2021 The Author(s)}

Published by Human Resource Management Academic Research Society (www.hrmars.com) This article is published under the Creative Commons Attribution (CC BY 4.0) license. Anyone may reproduce, distribute, translate and create derivative works of this article (for both commercial and non-commercial purposes), subject to full attribution to the original publication and authors. The full terms of this license may be seen

at: http://creativecommons.org/licences/by/4.0/legalcode

\section{Vol. 11, No. 2, 2021, Pg. 771 - 783}

Full Terms \& Conditions of access and use can be found at http://hrmars.com/index.php/pages/detail/publication-ethics 


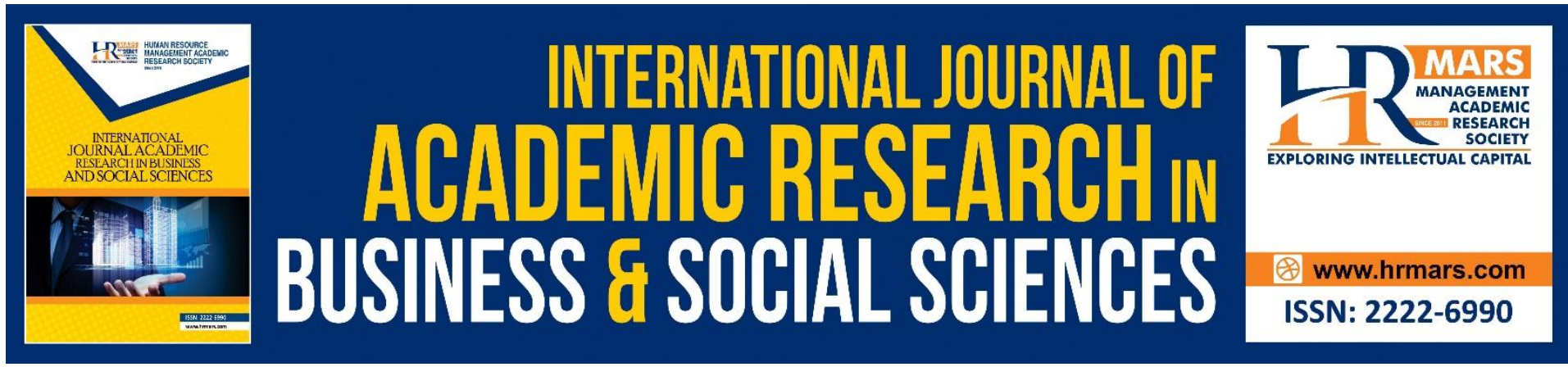

\title{
A Comparative Analysis of Tanazul And Conditional Hibah In Preference Shares
}

\author{
Azlin Alisa Ahmad, Siti Mutiara Mohd Azman \\ Centre for Sharia, Faculty of Islamic Studies, Universiti Kebangsaan Malaysia, Bangi, \\ Selangor, Malaysia \\ Nadhirah Nordin \\ Faculty of Contemporary Islamic Studies, Universiti Sultan Zainal Abidin, Terengganu
}

\begin{abstract}
Conditional hibah has been proposed to be practiced in preference shares as an alternative to tanazul which has triggered some of the shariah issues in recent practice. Although the use of tanazul is permissible, some of the shariah issues that arise in the practice of tanazul made it improper to practice. In a sequence, a conditional hibah has been proposed as an alternative. Thus, this study attempts to compare between the application of tanazul and conditional hibah in the preference shares. This article will compare both (tanazul and conditional hibah) through five aspects specifically definitions, utterance of offer and acceptance, pillars and conditions, results and transfer of ownership. This study is a qualitative study using content analysis method. The data was analized using descriptive and deductive techniques. The findings showed that although tanazul and conditional hibah are seen to be similar and have the same ultimate effect of nullification of rights, however the terms and elements used between them are different.
\end{abstract}

Keyword: Preference Shares, Conditional Hibah, Tanazul

\section{Introduction}

The conditional hibah and tanazul concept almost have similarity in term of transfer of proprietary rights. However the conditional hibah is different from the tanazul in some situations. The reason of prohibition of using tanazul in the preference shares was not caused by the tanazul contract is not Shariah compliant, however due to the current practice adopted in tanazul which is discordant to the law of $I \mathrm{bra}^{\prime}$ (rebate), which is the urgency of the existence of the subject of contract to eliminate the irrelevant right. Despite of the opinions that allow the use of tanazul in the Preference shares, however the current practices carried out in the contract of preference shares has triggered shariah issues that need to be considered.

Thus, the debate over the comparison of conditional hibah and tanazul is very important in order to make the conditional hibah may overcome the shariah issue existed in tanazul, which is prohibited in Islam. Therefore, this study does not imply a hibah that produces the same effect, diversely the conditional hibah intended in this study defined as two separated contracts that not deliver the same effects. 
Although the Malaysian Securities Commission allows tanazul in the Preference shares (Securities Commision Malaysia, 2007), somehow the tanazul that practiced at the beginning of the Preference shares contract had contributed to the shariah issues. Tanazul done in the beginning of the contract involving the nullification of rights for something that has yet to exist and then causing the gharar in tanazul and the collision of essence of contract (muqatada caqd). Gharar is among the element that are not allowed in Islam and in all Muamalat contracts including the usury (riba) and maysir (gambling). The sequence of the existence of gharar (uncertainty) in tanazul and the collision muqtada caqd in tanazul applications, therefore tanazul contract not qualified to apply in preference shares. Hence, the purpose of this study is to compare between the application of tanazul and conditional hibah in the preference shares contract.

The main difference in the concept of tanazul currently practiced in Preference shares and conditional hibah is the existence and the absence of the aqad subject. The practiced of tanazul undertake in exterminating the proprietary of right that has not existed (Marina 2014). While the conditional hibah abort something that already exists, because it was two isolated contracts. In fact, conditional hibah that was proposed in this study take place at the end of the contract, which is in the second contract after generating the profit or loss. This is in line with the saying from the Hadith of Rasulullah saw عتق ولا تملك فيما ، تملك فيما إلا طلاق لا إلا. Conditional hibah is irrelevant and unreliable between two locked contracts. Conditional hibah only engage in terms of promise. Islam strongly urged its followers to fulfill the mutual promise.

Tanazul is also different with a conditional hibah in terms of the conditions and the occurrence time during transferring the ownership rights. In the situation of conditional hibah, the requirements to transfer the ownership rights is at the end of the formality event, after the existence of the subject of contract and after generating profit or loss, while in tanazul, nullification of rights happen in early tanazul that is when the early contract been locked before subject of contract exist.

Therefore, it can be concluded that a conditional hibah is different from the tanazul from period aspect of the rights nullification. This is because in tanazul, the nullification period occurs at the beginning of the contract when the subject of contract does not exists yet. This matter has affected the existence of shariah issues that are prohibited in Islam. Hence, the next section will be explained in detail some aspects of the comparison between both conditional hibah and tanazul.

\section{Comparison between Tanazul and Conditional Hibah by its Definitions}

Conditional hibah in preference shares refers to two contracts carried out by a party that promised to give a hibah to the other party by concerning the requirement of certain matters. For example, promise to give hibah towards profit or loss. The two contracts must separate and have no relation to each other. The hibah also committed between the two parties as a guarantee that the plaintiff will fulfill his promise. Conditional hibah in preference shares only refers to two separate contracts made by the two parties to implement aqad hibah in the future. The first contract is the only promise to sign the hibah contract in the future. While the actual hibah will only occurred once the offer and acceptance is completed at the end of the event, once the profit or loss generated.

The definition of a conditional hibah is different from tanazul. Tanazul defined as nullification of rights on allegation (Securities Commission Malaysia, 2007) or been waived on someone's rights (Bank Islam Malaysia Berhad, 2010). The right in the context of preference shares is 
referred to profit or loss. The rights that been released (cancelled) was given to someone other than the original owner of the rights concerned (Wizarat al-Awqaf wa al-Shucun alIslamiya, 1986). Tanazul Agreement took place in early signing of the contract (Aznan, 2011). The principle of tanazul practiced in Preference shares as only a condition of the contract to waive those rights (Wizarat al-Awqaf wa al-Shucun al-Islamiya, 1986). With this, it can be concluded that conditional hibah in the Preference shares is different with tanazul because conditional hibah is just a notification of the promisor about his desire to do hibah grant in the future, whereas tanazul is consent at the beginning of the contract that binding and executed contract between the two parties.

Based on the comparison of conditional hibah and tanazul by its definition, it can be concluded that the first contract in the conditional hibah is a promise that will bound in the future. While tanazul is a contract which takes place at the beginning of the contract. The first contract, which is valid in conditional hibah only a promise to accomplish hibah, rather than the establishment of a hibah contract itself. The primary goal of conditional hibah in preference shares is to establish a hibah (execution) in the future. While the initial goal of tanazul in Preference shares is to give ownership, means that, to give proprietary rights of common holders became Preference shares holder or vice versa. Therefore, conditional hibah in the preference shares cannot be associated with tanazul because the definitions for both are different.

Table 1 Comparison Analysis Between Conditional Hibah Bersyarat and Tanazul In Term of Definition

\begin{tabular}{|c|c|c|}
\hline Features & Tanazul & $\begin{array}{l}\text { Conditional } \\
\text { Hibah }\end{array}$ \\
\hline Two different contract & $X$ & $\mathrm{~V}$ \\
\hline Contract that nullify the proprietary rights & $\sqrt{ }$ & $\sqrt{ }$ \\
\hline Tranfer of the ownership occured & $\sqrt{ }$ & $\sqrt{ }$ \\
\hline With conditions & $\mathrm{X}$ & $\sqrt{ }$ \\
\hline Promise to bind contract in future & $\mathrm{x}$ & $\mathrm{V}$ \\
\hline Contract endorsed at the early of contract bind & 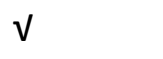 & $\mathrm{x}$ \\
\hline $\begin{array}{l}\text { Sealed contract occured when certain condition } \\
\text { been fulfilled }\end{array}$ & $x$ & 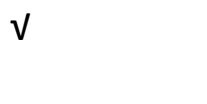 \\
\hline Once it bind cannot be invalid & $\mathrm{V}$ & 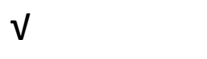 \\
\hline $\begin{array}{l}\text { Granting the subject (good/item) of the aqad } \\
\text { directly }\end{array}$ & $\sqrt{ }$ & $\mathrm{x}$ \\
\hline $\begin{array}{l}\text { It is compulsory to deliver the subject (good/item) of } \\
\text { the aqad at the beginning of the contract }\end{array}$ & $\sqrt{ }$ & $\mathrm{x}$ \\
\hline $\begin{array}{l}\text { The possession of the subject of the aqad took by the } \\
\text { recipient }\end{array}$ & V & $\mathrm{V}$ \\
\hline
\end{tabular}

\section{Comparison Tanazul and Conditional Hibah According to the Utterance of Offer and Acceptance}

There are several conditions in offer and acceptance to form a valid contract. Among them, offer and acceptance must reflect the wishes of contracting parties (subject aqad). Offer and acceptance should be clear and known to both parties as well as must affirm and complement to each other (Zaydan, 2005). 
When a conditional hibah in a preference shares is made, the hibah contract is still pending. Though, is just a binding agreement. The actual hibah contract will only apply when the profit or loss of the company had generated as agreed at the beginning of the contract. The actual hibah contract should had a valid ijab and qabul. Since the proclamation of the agreement had done at the beginning of the contract which bind in the future, then that proclamation is still not considered as a contract.

There are examples involving three situations. The first situation, the common shareholder, said to Preference shares shareholders that "I promise to grant my right (to do hibah) to get a profit by allowing the shareholders from Preference shares gain in advance the profit on a certain basis". The second situation, a shareholder from Preference shares said to ordinary shareholders that "I promise to grant my right (to do hibah) to gain profit more than the prescribed rates". The third situation, the common shareholder, said to the shareholders of Preference shares that "I promise to grant my rights right (to do hibah) as a" winding-up "situation by prioritizing priority shareholders from Preference shares to regain their contributed capital.

The utterance "I promise I will grant the hibah" it shows that something will be occurred in the future. Then the utterance of the offer and acceptance made at the beginning of the contract did not endorse the hibah contract even during the proclamation of offer and acceptance. This is because, the contract will not happen beside an utterance or an agreement to perform something in the future (al-Hattab, 2000). In fact, it is impossible if the utterance of word "will" show the immediate action, because the word "will "refer to an act in the future. Thus, the hibah is absolutely be implemented in a next period as prescribed, either during generating a profit or a loss.

The promise should be made using utterance that shows it will happen in the future. If the utterance shows it happen now, therefore it is not a promise. The time to fulfill the promise is in the future. Therefore, if it already happens or still currently happen so it considered that the promise still not been fulfilled. Thus, the promise is not an agreement (aqad), but then it is not necessary to do ijab and qabul (ISRA, 2010). In the context of Preference shares, promises that are declare at the beginning of the contract give a meaning of a future. So, it is merely a promise to do hibah in the future instead of during the time of an agreement being endorsed.

This is different with the utterance of the offer and acceptance in the tanazul because tanazul occurs when the utterance of the offer and acceptance been uttered. The utterance of the offer and acceptance in the tanazul give immediate effect which is tanazul or nullify the rights that occur during the utterance of the offer and acceptance. This shows that conditional hibah varies with tanazul due to the implementation of aqad in tanazul is mandatory at the beginning of the contract been completed.

In addition, tanazul is not valid if it is associated with any condition. This is because, tanazul must be done immediately and cannot be deferred (Ibn al-Hummam, 2003). Thus, with the resignation the conditions, it show there is no tanazul aqad immediately, otherwise will only occur once the matter is in the certain condition had been fulfilled. For example, if party $A$ says I tanazul my right to the $B$ with condition after the company earned a profit and then give priority to party $B$ in advance to earn the profit. Or the $B$ says: I tanazul my excess profit right to the $A$, with condition after the company earned a profit by limiting it at specific rates only.

This kind of contract in tanazul is invalid because it is associated with certain conditions. In fact, such contracts will only occur in the future which is not allowed in the contract of tanazul 
(al-Buhuti, 1983). Whereas the tanazul aqad should take effect immediately during signing the contracts without any delay. In contrast, hibah remain valid even if certain conditions are placed or associated with a specific reason (Ibn Rushd, 1415H). Such hibah are called or known as a conditional hibah.

When the conditional hibah contract is done, the hibah did not take place yet. Hibah will only occur if there is subject matter, after the existence of the requested condition. This is because the consent of conditional hibah is made at the beginning of the contract is merely a promise to do hibah in the future, not during the time the promise was made. The agreement between ordinary shareholders and Preference shares shareholders are only promises to conditional hibah only, instead of showing the formation of the hibah contract. Therefore, the use of utterance that gives a meaning in future in tanazul contract is invalid because tanazul contract must be done immediately.

Table 4.2 shows the comparison analysis between tanazul and conditional hibah from the aspect of utterance of ijab and qabul:

Table 2 Comparison analysis between tanazul and conditional hibah from the aspect of utterance of ijab offer and acceptance

\begin{tabular}{|c|c|}
\hline Conditional Hibah & Tanazul \\
\hline Uttered: "I promise to do hibah" & $\begin{array}{l}\text { Utterence of offer and acceptance in tanazul } \\
\text { made tanazul happened immediately }\end{array}$ \\
\hline $\begin{array}{l}\text { Phrase "will" refer to some action will be } \\
\text { done in future }\end{array}$ & $\begin{array}{l}\text { tanazul occured during the utterence of } \\
\text { offer and acceptance been uttered not in } \\
\text { future }\end{array}$ \\
\hline $\begin{array}{l}\text { Hibah contract is valid with the proposition } \\
\text { of any condition in utterence }\end{array}$ & $\begin{array}{l}\text { Invalid if there is proposition of condition in } \\
\text { the utterence that change the contract will } \\
\text { occur in future. }\end{array}$ \\
\hline $\begin{array}{l}\text { Uteerence of contract that will occur in } \\
\text { future is allowed }\end{array}$ & $\begin{array}{l}\text { The utterence should show that the conract } \\
\text { occur immediately }\end{array}$ \\
\hline
\end{tabular}

\section{Comparison between Tanazul and Conditional Hibah According to Pillar and Condition}

The pillars and conditions are an important element for establishing a contract (al-Qarafi 2001). Any contract endorsed should have the main doctrines such as contracting parties, the subject of the contract and offer and acceptance (al-Suyuti, 1983, al-Sharbini, 2000; Ibn Juzay, n.d). Each pillar also has certain requirements that are binding together. All the pillars and conditions should be fulfilled to ensure that the contract is valid in term of Islamic law. If one of the pillars or the conditions are not met, then the contract will be invalid.

Pillars and conditions for tanazul will refer to the pillars and conditions in ibra' because tanazul in figh known as isqat. While the term of isqat is closely related to the concept $i b r a$ '.Thus, the discussion of pillars and conditions of tanazul will refer to the ibra 'as both is closely related. While the pillars and conditions for the conditional hibah will also refer to the basic pillars and conditions in hibah because conditional hibah is a part of the hibah contract. Thus, both hibah and conditional hibah applies the same pillars and conditions, however the difference is the deployment of the conditions stipulated in the conditional hibah.

There are four pillars in ibra'; first is mubarri' which is refers to the party that gives ibra', second is mubarra' which is refers to the party receiving the ibra', third is mubarra' minhu which is refers to the thing that been ibra', and fourth is șighah which is refers as offer and acceptance of ibra' (Ibn cAbidin, 2003; al-Dardir t.th; al-Buhuti, 1983). While the pillars of hibah is al-wahib that is the giver of hibah, al-mawhub is the one that is the recipient of a 
hibah, macqud calayh namely property that is eligible and șighah consists of the ijab and qabul (al-Qarafi, 1994; al-Rafici, 1997; al-Ardabili, 2006; al-Sharbini, 2000; al-Hajjawi 2002; Ibn Dawayyan t.th).

The party who is giving the ibra' is known as mubarri, must be a qualified based on the given terms. They have the right to ibra' and do the it voluntary (Ibn cAbidin 2003; al-Dardir t.th; alBuhuti 1983). Meanwhile, the contract in hibah, the party who is giving the hibah known as al-wahib. They must be qualified from the terms that been set; such as wise (sensible), matured, judiciuos, and allowed to manage their own property, as well as valid owner of the property (Ibn Rushd, 1415H; al-Sharbini, 2000; al-Qarafi, 1994; Nizam t.th; al-Buhuti, 1993). Secondly, the party receiving the ibra' is known as mubarra'; must be a creditible person (alSuyuti, 1983; al-Buhuti, 1983). Meanwhile, the recipient of the hibah or al-mawhub is able to do qabd on the property under hibah offered to him. Therefore, the hibah given to underage children is a valid, however, qabd should be practiced by those have the credentials such as his guardian (al-Sharbini, 2000; al-Zarkashi, 2009).

Thirdly is the subject of the contract. The ibra' or mubarra' minhu must be clear. It is invalid process for the ibra' if the amount not clearly stated (al-Qalyubi, 1956). Moreover, the things that been ibra' must be existed when ibra' is complete. This is because, it is an impossible to eliminate the right that does not exist. The procedure of $i b r a^{\prime}$ is invalid if been aimed for the future time (al-Buhuti, 1983).

In addition, macqud calayh must be existed during the procedure of hibah (al-Kasani 2003; Niẓam t.th; al-Shirazi, 1996; al-Nawawi, 1991; Ibn Qudamah, 1997; al-Mardawi, 1956). However, the Maliki judgemented that, as a valid grant of property which majhul and unknown. This is because the existence of the element of gharar in the hibah which is a contract without retaliation is behove, which is not nulify the contract of hibah (al-Qarafi 1994; al-Hattab 2010; al-Zarqani, 2002). In addition, items that been use as hibah must also belong to the donor (al-Kasani 2003). Beside that, the item must be valuable. There are items that cannot be granted as hibah; such as alcohol (al-Kasani 2003). Other than that, the item must be separated and cannot be connected with the property that is not included in the hibah (al-Kasani, 2003; Ibn cAbidin, 2003; al-Samarqandi, 1984). Then, the procedure must be proceed with the process of qabd for the hibah (al-Samarqandi, 1984; al-Kasani, 2003; alSarakhsi t.th; Qaḍi Zadah, 1315H; al-Shirazi, 1996; al-Rafici, 1997; al-Nawawi, 1991; alSharbini, 2000; Ibn al-Mundhir, 2005).

Finally is șighah referred as offer and acceptance. Sighah is very important for contract process that showed the offer or acceptance for the particular individual (Faizah, 2000). Sighah also described the process of the agreement to sealed the contract (al-khafif, 2009; alKhayyat, 1994). șighah can be in different situation such as utterance, documentation, and action (al-Khayyat, 1994).

Șighah can be done in form of documentation within the rules of the contract for Preference shares. The implemented șighah only concealed a promise for the future because both parties whether the common share holders or the Preference shares holders in șighah that hibah can only be completed based on the profit or loss of the company. For example, the holder of the common shares make a bid in the șighah such as "I promise to give hibah and agree to the terms and will hand over the possession of this profit to you with prioritize you for the profit rate has been set". Then, this procedure is followed by the sighah for acceptance from the holder of the prior shares such as "I agree with conditions and will take the possession". Even though șighah done in the beginning of the contract procedure, hence the the actual hibah only occured after the condition been fulfilled. Tanazul is differed to șighah, because șighah 
been done in the beginning of the contract while tanazul is occured immediately after the acceptance of the person.. For example, "I have tanazul the right profit with prioritize you earn profit in advance". Then followed with șighah of acceptance "I accept".

These four elements should be presented in the formation of tanazul and conditional hibah, it is clear that the the principles of conditional hibah is more appropriate to be practiced in Preference shares compared to the principles of tanazul. The proposed for the conditional hibah will only be completed in the final piece of the contract where the subject of the contract that is already existed. This thing is laterally with the hadith of the Prophet لا طلاق إلا فيما تملك ، ولاعتق إلا Muhammad which became the main policy in this study that فيما تملك.

Indirectly, the principles of conditional hibah is also able to overcome the issue of shariah occured during the application of tanazul. Sharia issue is among the elements that are not allowed to be occured in sealed contract. Because, the existence of the shariah issue would nullify the sealed contract. Table 3 shows the comparative analysis between the conditional hibah and tanazul based on its pillars and conditions:

Table 3 A comparative analysis between the conditional hibah and tanazul from the aspect of the pillars and conditions

\begin{tabular}{|c|c|c|}
\hline $\begin{array}{l}\text { Aspects } \\
\text { Comparison }\end{array}$ & Conditional Hibah & Tanazul \\
\hline The grantor & $\begin{array}{l}\text { al-Wahib } \\
\text { - qualified the terms (wise or } \\
\text { sensible, matured, judiciuos) } \\
\text { - allowed to manage their own } \\
\text { property } \\
\text { - valid owner of the property }\end{array}$ & $\begin{array}{l}\text { Mubarri' } \\
\text { - qualified the terms (wise (sensible), } \\
\text { matured, judiciuos) } \\
\text {-have the right to granted } i b r a^{\prime} \\
\text {-voluntaraly do the } i b r a^{\prime}\end{array}$ \\
\hline The reciepient & $\begin{array}{l}\text { al-Mawhub lah } \\
\text {-should not be required as (wise or } \\
\text { sensible, matured, judiciuos) } \\
\text { - the receiver of the hibah must be } \\
\text { able to do the qabd on the property } \\
\text {-for underage children, the qabd } \\
\text { should be practiced by those have } \\
\text { the credentials such as his wali or } \\
\text { guardian }\end{array}$ & $\begin{array}{l}\text { Mubarra' } \\
\text { - known and identified }\end{array}$ \\
\hline Subject of akad & $\begin{array}{l}\text { Macqud cAlayh } \\
\text {-existed (from the view of Maliki } \\
\text { hibah is valid from unknown } \\
\text { property or majhul) } \\
\text {-belong or own by the hibah } \\
\text { grantor } \\
\text {-valuable from the view of syara' } \\
\text {-splitted and not connected with } \\
\text { the property not included in hibah } \\
\text { process } \\
\text {-existence of qabd on the property } \\
\text { been hibah }\end{array}$ & $\begin{array}{l}\text { Mubarra' Minhu } \\
\text {-the existance is recognized } \\
\text {-existed during the process of } i b r a^{\prime} \\
\text { - ibra' which is aimed for future time } \\
\text { is invalid }\end{array}$ \\
\hline Offer and Acceptance & $\begin{array}{l}\text { Utterance of offer such as "will" } \\
\text { affect the on the hibah process for } \\
\text { the future time }\end{array}$ & $\begin{array}{l}\text { Utterance of offer that be used } \\
\text { affected the tanazul for the } \\
\text { meantime }\end{array}$ \\
\hline
\end{tabular}




\section{Comparison of Tanazul and Conditional Hibah According to Corollary}

Other aspects that distinguish between tanazul and conditional hibah is; tanazul affected immediately. Tanazul immediately will happen after the sealed contract at the beginning of the contract between both parties. Tanazul is valid as soon as the completion of ijab and qabul. Therefore, if tanazul done on a delay period or aimed to do in future period is invalid. Thus, tanazul done by the qualified person on identified as well as the ownership status on the property would immediately disqualified his right to a other person, also on the ownership of the property.

Hence, the conditional hibah is the act of delaying the act of hibah for the future time purpose and does not bind directly at the present time. Conditional hibah only act as a notification and consent for the future period. Thus, the effect of hibah will occur in the future not during the sealed contract process.

Contract of tanazul and conditional hibah differ in term of the outcome, where the outcome for the conditional hibah will happen in future perion, while tanazul will happen in present period of time. The outcome of the conditional hibah on the subject of the contract does not occur unless in future period time as agreed. This contrasted with the outcome of the tanazul; which is happen for the present period. Tanazul can not be aimed for the future period because if tanazul been delay, there would be element of gharar because of the uncertainty to happen or not. In fact, this will lead to invalid the act of tanazul. Therefore, tanazul only valid for the purpose of present period of time.

Conditional hibah in the first contract is referred as pledge where the offer and acceptance has not yet occurred, as well as the act of hibah. Conditional hibah is a pledge for the purpose of hibah contract in the form of tabarruc. This procedure did not form the contract of hibah. Even though the sealed contract is occurred between both parties, but the consequence is only going to happen in the future period time. Then the obligations of the consequence of promises made also only will happen in the future.

Table 4Analysis on comparative between conditional hibah dan tanazul from the aspect of contract's consequence

\begin{tabular}{|c|c|c|c|c|c|}
\hline $\begin{array}{l}\text { Corollary } \\
\text { Contract }\end{array}$ & $\begin{array}{l}\text { Nulifacation } \\
\text { of right }\end{array}$ & $\begin{array}{l}\text { Transformation } \\
\text { of ownership }\end{array}$ & $\begin{array}{l}\text { Time of } \\
\text { occurred }\end{array}$ & $\begin{array}{l}\text { Delaying/ } \\
\text { immediate }\end{array}$ & $\begin{array}{l}\text { Number } \\
\text { contract }\end{array}$ \\
\hline $\begin{array}{l}\text { Conditional } \\
\text { Hibah }\end{array}$ & V & v & $\begin{array}{l}\text { Final } \\
\text { contract } \\
\text { (second } \\
\text { contract) }\end{array}$ & delay & $\begin{array}{l}\text { Two } \\
\text { separated } \\
\text { contracts } \\
\text { (preliminary/ } \\
\text { final) }\end{array}$ \\
\hline Tanazul & v & v & $\begin{array}{l}\text { Preliminary } \\
\text { contract } \\
\text { (first } \\
\text { contract) }\end{array}$ & immediate & $\begin{array}{l}\text { One contract } \\
\text { (preliminary) }\end{array}$ \\
\hline
\end{tabular}

\section{Comparative of Tanazul and Conditional Hibah Based on The Transfer of Ownership}

Tanazul in the context of prior share referred as the act of nullification of the right to gain profit either in full or half or in loss condition. (Aznan 2011). The nullification of the right in tanazul will lead to transformation of the ownership from one party to another party. This process cannot be delayed or for the future period of time. This mean that, ownership 
transformation must be done in the present time without time delaying. Thus, the person that been nullified of his right will own the subject after the sealed contract of tanazul.

There is no transformation of property ownership happen in conditional hibah act, and there is no obligation on the ordinary shareholders or major shareholders to nullify their rights because the contract of the hibah did not occur in the first contract (preliminary). The contract of conditional hibah only completed in second contract (final contract) with the completion of the terms. This thing is laterally with the hadith of the Prophet Muhammad which became the main policy in this study that is لا طلاق إلا فيما تملك ، ولا عتق إلا فيما تملك.

The agreement at the beginning sealed contract is meaningless, thus there is no transformation of the subject of contract happen. In conditional hibah, the subject of contract did not have to transfer yet, where the situation is differ in act of tanazul. Thus, if the first agreement is meaningless, there is no ownership transformation occurred. Nevertheless, the ownership transformation for the subject of contract will not occurred unless the terms is contended.

Based on the discussion, it can be concluded that conditional hibah is differs with tanazul. Therefore, the principle of conditional hibah can be study in further to enable it to be structured in Preference shares and indirectly able to develop products of the Islamic capital market to be more innovative and competitive products compared to conventional capital market.

Table 5Analysis on comparative between tanazul dan conditional hibah from the ownership transformation aspect

\begin{tabular}{|c|c|}
\hline Conditional hibah & Tanazul \\
\hline Did not immediately sealed & Immediately effected \\
\hline $\begin{array}{l}\text { Delaying the act of hibah for the future } \\
\text { period of time }\end{array}$ & Happen in the beginning of contract \\
\hline $\begin{array}{l}\text { Valid with the terms for the future time } \\
\text { purpose }\end{array}$ & Invalid for the delaying and future time \\
\hline $\begin{array}{l}\text { Only act as announcement and agreement } \\
\text { to conclude the obligations for the future }\end{array}$ & $\begin{array}{l}\text { Nullification of the rights or immediately } \\
\text { extrication of the rights at the beginning of } \\
\text { the contract }\end{array}$ \\
\hline $\begin{array}{l}\text { hibah only happen in future time (the } \\
\text { transformation of the ownership also will } \\
\text { happen in future) }\end{array}$ & $\begin{array}{l}\text { There is instant ownership transformation } \\
\text { of the property }\end{array}$ \\
\hline
\end{tabular}

Table below concluded the analysis on the comparative between conditional hibah and tanazul. 
Table 6Conclusion based on the analysis comparative between conditional hibah and tanazul

\begin{tabular}{|c|c|c|}
\hline $\begin{array}{l}\text { Apect } \\
\text { comparative }\end{array}$ & Conditional Hibah & Tanazul \\
\hline Definition & $\begin{array}{l}\text { Agreement to do hibah for } \\
\text { the future time purpose; } \\
\text { when the stated condition } \\
\text { happen }\end{array}$ & $\begin{array}{l}\text { Agreement between partnerships to } \\
\text { do the tanazul on his rights either to } \\
\text { half or fully extricate on profit or loss } \\
\text { during the extrication }\end{array}$ \\
\hline $\begin{array}{l}\text { Utterance of offer } \\
\text { and acceptance }\end{array}$ & $\begin{array}{l}\text { Sealed for the future time } \\
\text { purpose with the use of } \\
\text { utterance "will do the hibah" }\end{array}$ & $\begin{array}{l}\text { Utterance of ijab and qabul for } \\
\text { immediate time purpose not for the } \\
\text { future }\end{array}$ \\
\hline $\begin{array}{l}\text { Decree } \\
\text { condition }\end{array}$ & $\begin{array}{l}\text { al-Wahib } \\
\text { al-Mawhub lah } \\
\text { Macqud cAlayh } \\
\text { Sighah }\end{array}$ & $\begin{array}{l}\text { Mubarri' } \\
\text { Mubarra' } \\
\text { Mubarra' Minhu } \\
\text { Șighah }\end{array}$ \\
\hline $\begin{array}{l}\text { Implementation of } \\
\text { contract }\end{array}$ & $\begin{array}{l}\text { Contract for conditional } \\
\text { hibah did not yet effective, } \\
\text { the agreement at the } \\
\text { beginning of the contract } \\
\text { only for act as binding } \\
\text { agreement. The actual } \\
\text { contract for conditional } \\
\text { hibah will effective after the } \\
\text { all the terms been completed }\end{array}$ & $\begin{array}{l}\text { Tanazul effective during the sealed } \\
\text { contract after the utterance of offer } \\
\text { and acceptance between two parties } \\
\text { at the beginning of the contract }\end{array}$ \\
\hline $\begin{array}{l}\text { Ownership } \\
\text { transformation }\end{array}$ & $\begin{array}{l}\text { There is no transformation of } \\
\text { the ownership because the } \\
\text { contract of hibah did not } \\
\text { effective yet. Will be } \\
\text { effective when the discussed } \\
\text { terms and condition fulfilled } \\
\text { based on the at the } \\
\text { beginning of the agreement }\end{array}$ & $\begin{array}{l}\text { There is ownership transformation } \\
\text { happen during the contract of tanazul }\end{array}$ \\
\hline Consequence & $\begin{array}{l}\text { Did not bind immediately, } \\
\text { the outcome only occurred } \\
\text { for the future time purpose }\end{array}$ & $\begin{array}{l}\text { The outcome will occurred after } \\
\text { tanazul been sealed. The valid tanazul } \\
\text { is the one immediately effective }\end{array}$ \\
\hline
\end{tabular}

\section{Conclusion}

Based on the previous discussion on the comparative aspects, the application for the conditional hibah is more suitable to be implemented in Preference shares compared to tanazul application. This is can be concluded based on the discussion on the definition, utterance of ijab and qabul (offer and acceptance), pillars and conditions. In addition, the aspects of comparative that have been discussed also able to overcome the Shariah issues occurred in tanazul which is prohibited in Islam. Hence, it can be concluded that implementation of conditional hibah is more suitable to be applied in Preference shares compared to tanazul.

\section{Acknowledgement}

The authors would like to acknowledge Ministry of Higher Education of Malaysia for funding 
the FRGS research grant entitled 'Pembinaan Parameter Islamic Swap dalam Pasaran Derivatif di Malaysia. Project Code: FRGS/1/2018/SS01/UKM/02/5.

\section{References}

Al-Ardabili, Y. I. (2006). al-Anwar li Acmal al-Abrar. Jil. 2. Kuwait: Dar al-Ḍiya'.

Aznan, H. (2011). Perlaksanaan Tanazul di dalam Kontrak Berdasarkan Musharakah: Perspektif Syarak. http://irep.iium.edu.my/id/eprint/24734, IIUM repository (IREP). Seminar Isu-Isu Shariah dalam Musharakah dan Mudarabah. Anjuran Majlis Penasihat Syariah, Bank Negara Malaysia dan Majlis Penasihat Syariah, Suruhanjaya Sekuriti Malaysia. Lanai Kijang. 15 November.

Bank Islam Malaysia Berhad. (2010). Application of Shariah Contracts in Islamic Banking Products and Services. Kuala Lumpur: Bank Islam Malaysia Berhad.

Al-Buhuti, M. Y. (1983). Kashshaf al-Qinac can Matn al-Iqnac. Jil. 3, 4 \& 5. Beirut: calam alKutub.

Al-Buhuti, M.Y. (1993). Sharh Muntaha al-Iradat: Daqa'iq Uli al-Nuha li Sharh al-Muntaha. Jil. 2. Beirut: calam al-Kutub.

Al-Dardir, A. M. (N.d.) al-Sharh al-Șaghir cala 'Aqrab al-Masalik 'ila Mazhab al-'Imam Malik. Jil. 3 \& 4. Qaherah: Dar al-Macarif.

Faizah, I. (2000). Asas-Asas Muamalat dalam Islam. Kuala Lumpur: Dewan Bahasa dan Pustaka.

Al-Hajjawi, S. (2002). Al-lqnac li Talib al-Intifac. Jil. 3. Riyaḍ: Darah al-Malik cabd al-caziz.

Al-Hattab, A. (2010). Mawahib al-Jalil fi Sharh Mukhtașar Khalil. Jil. 6. N.p: Dar al-Riḍwan.

Al-Hattab, K.T. M. (2000). Al-Qabḍ wa al-Ilzam bi al-Wacd fi caqd al-Murabahah li al-Amir bi al-Shira' fi al-Fiqh al-Islami. Muctah li al-Buhuth wa al-Dirasat 15(1): 233-259.

Ibn al-Humam, K. M. (2003). Sharh Fath al-Qadir cala al-Hidayah Sharh Bidayat al-Mubtadi. Jil. 6 \& 7. Beirut: Dar al-Kutub al-Ilmiyyah.

Ibn al-Mundhir, A.B.M. (2005). al-Ishraf cala Madhahib al-cUlama'. Jil. 7. UAE: Maktabah Makkah al-Thaqafiyyah.

Ibn cAbidin, M. A. (2003). Hashiyah Ibn cAbidin: Radd al-Muhtar cala al-Durr al-Mukhtar Sharh Tanwir al-Abșar. Jil. 4, 6, 8 \& 9. Riyaḍ: Dar cAlam al-Kutub.

Ibn Dawayyan, I. (N.d). Manar al-Sabil fi Sharh al-Dalil. Jil. 2. Dimashq: Dar as-Salam.

Ibn Juzay, A. Q. (N.d). al-Qawanin al-Fiqhiyyah fi Talkhis Madhhab al-Malikiyyah.

Ibn Qudamah, A. M. (1997). al-Mughni. Jil. 6, 7 \& 8. Riyaḍ: Dar cAlam al-Kutub.

Ibn Rushd, M. (1415H). Bidayah al-Mujtahid wa Nihayah al-Muqtașid. Jil. 3 \& 4. Qaherah: Maktabah Ibn Taymiyyah.

ISRA. (2010). ISRA Compendium for Islamic Financial Terms: Arabic-English. Kuala Lumpur: International Shariah Research Academy for Islamic Finance.

Al-Kasani, A. D. (2003). Bada'ic al-Șana'ic fi Tartib al-Shara'ic. Jil. 4, 6, 7 \& 8. Beirut: Dar alKutub al-cilmiyyah.

Al-Khafif, A. (2009). Al-Syarikat fi al-Fiqh al-Islami Buhuth Muqaranah. Qaherah: Dar al-Fiqh al-carabi.

Al-Khayyat, A. A. (1994). Al-Sharikat fi al-Sharicah al-Islamiyyah wa al-Qanun al-Wadci. Jil. 1. Beirut: Mu'assasah al-Risalah.

Al-Mardawi, A. D. (1956). Al-Inșaf fi Macrifat al-Rajih min al-Khilaf. Jil. 7. N.d: Matbacah alSanah al-Mahmudiyyah.

Marina, A. B. (2014). Wacd bi al-tanazul dalam amalan saham keutamaan menurut perspektif Islam. Disertasi Ijazah Sarjana, Jabatan Syariah, Universiti Kebangsaan Malaysia. 
Al-Nawawi, A. Z. (1991). Rawḍt al-Talibin. Jil. 5. Beirut: al-Maktab al-Islami.

Niẓam. (N.d). Al-Fatawa al-Hindiyyah. Jil. 4. Beirut: Dar Șadir.

Zadah, Q. S. A. (1315H). Takmilah Sharh Fath al-Qadir: Nata'ij al-Afkar fi Kashf al-Rumuz wa al-Asrar. Bulaq: Matbacah al-Kubra al-Amiriyyah.

Al-Qalyubi, S., Cumayrah, S. A. (1956). Hashitan. Jil. 2 \& 3. Meșir: Muștafa al-Babi al-Halabi wa Awladuh.

Al-Qarafi, A. I. (2001). Kitab al-Furuq: Anwar al-Buruq fi Anwac al-Furuq. Jil. 2, 3 \& 4. Qaherah: Dar al-Salam.

Al-Qarafi, S. A. (1994). Al-Dhakhirah. Jil. 6 \& 7. Beirut: Dar al-Gharb al-Islami.

Al-Rafici, A. Q. (1997). Al-caziz Sharh al-Wajiz. Jil. 5 \& 6. Beirut: Dar al-Kutub al-cilmiyyah.

Al-Samarqandi, A. (1984). Tuhfat al-Fuqaha'. Jil. 3. Beirut: Dar al-Kutub al-cilmiyyah.

Al-Sarakhsi, S. (N.d). Al-Mabsut. Jil. 12. Beirut: Dar al-Macrifah.

Securities Commission Malaysia. (2007). Resolutions of the Securities Commission Shariah Advisory Council. $2^{\text {nd }}$ Ed. Kuala Lumpur: Securities Commission.

Al-Sharbini, S. M. (2000). Mughni al-Muhtaj Ila Macrifah Macani al- Alfaz al-Minhaj. Jil. 2, 3 \& 4. Beirut: Dar al-Kutub al-cilmiyyah.

Al-Shirazi, A. I. (1996). Al-Muhadhdhab fi Fiqh al-Imam al-Shafici. Jil. 3. Damsyik: Dar al-Qalam.

Al-Suyuti, J. A. (1983). Al-Ashbah Wa al-Naza'ir fi Qawacid wa Furuc Fiqh al-Shaficiyyah. Beirut: Darul Kutub al-cilmiyyah.

Al-Zarkashi, S. A. (2009). Sharh al-Zarkashi cala Matan al-Khiraqi. Jil. 2. Makkah: Maktabat alAsadi.

Al-Zarqani, A. (2002). Sharh al-Zarqani cala Mukhtașar Khalil. Jil. 7. Beirut: Dar al-Kutub alcilmiyyah.

Zaydan, A. K. (2005). al-Madkhal li Dirasah al-Sharicah al-Islamiyyah. Beirut: Mu'assasah alRisalah. 